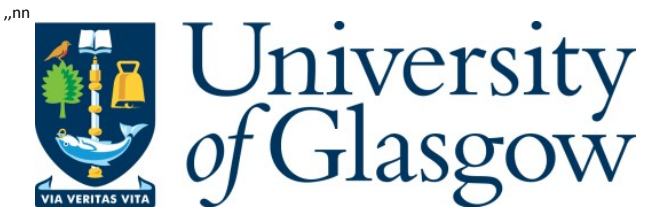

Park, C. (2015) Dental care professionals and child protection: case scenarios and discussions. Primary Dental J ournal, 4(4), pp. 52-55.

Copyright @ 2015 Faculty of General Dental Practice (UK)

http://eprints.gla.ac.uk/113592/

Deposited on: 16 December 2015

Enlighten - Research publications by members of the U niversity of Glasgow http://eprints.gla.ac.uk 


\title{
Christine Park
}

\author{
Author \\ Christine Park BSc(Dent Sci), BDS(Hons), MSc, MFDS, MPaed Dent RCSEd \\ Clinical lecturer/ Honorary P ost CCST StR in Paediatric Dentistry
}

\section{Abstract}

Any concerns about paediatric patients in general dental practice can be stressful for all involved. Barriers to the reporting of concerns by dental teams are known to exist. Anything that can help ease those situations can only be beneficial. In this article we look at three scenarios which could arise which I am often asked about during teaching and training sessions on safeguarding and child protection for dental teams. They can be discussed at team meetings and training, so that if they were ever to happen for real, everyone will know exactly what to do. This article cannot be completely prescriptive as there will be local variations, but it gives general guidance on issues raised by the scenarios. If you already have a child protection policy in your practice, make sure you know what it says; and if you don't this article will point the way to further resources for developing one.

\section{Key words}

Child Protection, Safeguarding Vulnerable Children,

Practice Child Protection Policies,

Child Protection Scenarios,

\section{Introduction}

Many members of the dental team find some areas of child protection challenging. Both in the UK and internationally there is a known gap between the numbers of dental professionals who suspect child abuse/neglect and those who actually refer cases. ${ }^{1-11}$ This has been reported both for dentists ${ }^{1,2,4-11}$ and for dental care professionals (DCPs)., Previously some barriers have been identified as contributing to this gap, such as lack of knowledge of referral procedures, concerns about impact on the child or practice, and lack of 
certainty of the diagnosis. ${ }^{1,2}$ In this article we discuss some potential situations that could arise in dental practice and suggest potential ways forward for dental teams to work together to face them.

\section{Scenario one}

You have entered the waiting room in your practice to call in the next patient. It is a busy day, which is normal for your practice. In the waiting room you (and everyone else) witness a mother slap her seven-year-old child across the face, leaving behind and imprint of her hand. What do you do?

\section{Discussion of issues in scenario one}

In the scenario above you have witnessed an assault. ${ }^{12-14}$ If this had happened to a competent adult, the adult themselves could ask for help and decide whether they wished to report the incident to the police. However in this case, the child is far more vulnerable and we must ensure their safety and wellbeing. This incident needs to be reported to the police who will then decide whether it needs further investigation. The police are skilled at interviewing and will be able to establish whether they have enough evidence to charge a parent. It is certainly illegal to hit a child on the head in Scotland; ${ }^{12}$ and in England and Wales it is illegal to hit a child if it causes bruising, swelling, cuts, grazes or scratches. ${ }^{13}$ Dental teams are not expected to investigate incidents themselves, but they are expected to observe, record and report. A scenario such as this would be upsetting and distressing for all involved. It is a good idea to have a practice policy and protocol in place that everyone knows about and understands, so that if this situation ever does occur in your practice, everyone knows exactly how to respond as well as how to support each other. ${ }^{15}$

The member of staff will need support from their other team members as well as the child protection lead for the practice. Other practical considerations would include working as a team to find out if the child or mother involved in the incident are here for treatment themselves. Whether treatment can still be provided would depend on how upset the child and mother were and whether the treatment planned for the visit is urgent or not. Treatment can still be offered, although the mother may be upset and decide to leave the practice, taking the child with them. Dental staff cannot physically stop this, but a record of all events, discussions (with any observed descriptions of tone of voice, etc), what treatment was offered, and reasons for refusal should be kept in the relevant incident reporting system. A record of events can also be kept in the child's dental notes if they are patient of the practice. 
Safeguarding the welfare of all children is a responsibility that rests upon the shoulders of everyone. It is well recognised that approximately $60 \%$ of all injuries in abuse cases are to the head and neck area. ${ }^{16-18}$ These areas are normally visible to members of the dental team, making them well placed to help identify cases of child abuse. Additionally, dental teams hold important information about the oral health of their paediatric patients, as well as information on attendance patterns. It is recognised that children who are confirmed cases of abuse or neglect, and even those for whom welfare concerns exist but no diagnosis of abuse or neglect has yet been made, generally tend to have poorer oral health than the wider paediatric population. ${ }^{19-24}$

\section{Scenario two}

You are assisting one of the dentists who works in your practice. It is the time of day when emergency patients are seen. The next patient who comes in is a seven- year-old who is accompanied by one of her parents. The family have been patients of the practice for many years and this child was initially registered with the practice when she was one year old. This child is only brought to the dentist when she is in pain. The practice records show she had 12 carious primary teeth removed under general anaesthetic three years ago, and previous to the referral she had failed to complete multiple courses of treatment due to multiple failed appointments. Today she is presenting with an abscess related to one of her permanent molars, and when the dentist examines her they find all four first permanent molars are unrestorable, and her parent wants her to be referred for another general anaesthetic. She has not been seen for one year, and at the last visit her permanent molars had been noted as almost fully erupted with no caries or defects, but her oral hygiene is poor. What concerns would you have about this child and what is the policy in your practice for dealing with this?

\section{Discussion of issues in scenario two}

In the above scenario, your concerns would include that the child has been brought into the practice in pain when there is a pattern of this already established; she has not been brought to appointments in the past and so failed to complete courses of treatment; and she has previously had a general anaesthetic for dental treatment and now is likely to require a second dental general anaesthetic. These are concerning and alerting features for dental neglect. ${ }^{15,25}$ Three levels of response are recommended by the guideline " $C$ hild Protection and the Dental team" ${ }^{15}$ when members of the dental team have concerns about dental neglect. These are:

1. Preventive dental team management

2. Preventive multi-agency management 


\section{Child protection referral.}

The preventive dental team management involves an initial concentration of efforts on relieving pain and providing preventive care and advice in a realistic and achievable manner. This has to be done in supportive way with the family involved. Further information can be found on the Child Protection and the Dental Team website. ${ }^{15}$ Preventive multi-agency management involves sharing concerns with other professionals who are involved with the family, such as health visitors, general medical practitioners or social workers. This sharing of information allows dental teams to find out if any other professionals have concerns, and to work together with other health or social care professionals to plan the way forward. In a dental practice, the sharing of information would normally be done by the dentists treating the child, however it is important that any DCPs with relevant information share this with the dentist also (for example any observation of unusual interactions between parents and child not observed by the dentist). The last level of response would be a formal child protection referral. The details of how to do this and who to contact should be contained within the practice child protection policy, so it is clear what the responsibilities of team members are. The General Dental Council states that all members of the dental team must know who to contact for further advice and how to refer concerns to an appropriate authority. ${ }^{26}$ In some practices it will be the dentist treating the child who makes the referral, in others it may be the lead for child protection or safeguarding in the practice, however any member of the dental team can make a referral. If a DCP has significant concerns about the safety or wellbeing of a child, they are entitled to make the referral themselves. A child protection referral is usually made to the relevant social services department by telephone call in the first instance, followed up in writing.

\section{Scenario three}

An irate parent has arrived and is making a scene in the waiting room because one of the dentists has made a child protection referral about their child. The parent is threatening all the staff and saying they will tell everyone in the local area not to come to the practice, because everyone who works here "sticks their noses in where they are not wanted". How would this be handled in your practice? Who would deal with it normally? What if they are on leave? Does your practice have a policy for handling violence and aggression?

\section{Discussion of issues in scenario three}

This is the topic of one of the most commonly asked questions at child protection training events. It is of course understandably worrying and upsetting for all concerned. The parent in question should be handled in a similar way to any aggressive or violent patient. There are 
advice sheets regarding this available from the British Dental Association. ${ }^{27}$ Effective communication is very important in situations like this, and dental team members can draw on skills that many will have, such as conflict resolution, dealing with difficult situations and breaking bad news. The general advice for dealing with a situation such as this includes remaining calm, maintaining eye contact (but not too much), moving the parent to an area away from public view, listening to their concerns and acknowledging their grievances, maintaining a safe distance and calling for help. Reassuring the parent that everyone in the practice acts in the best interests to promote and safeguard the wellbeing of children can be useful, as can reminding the parent that it is the professional responsibility of dental team members to refer concerns they have about paediatric patients. Support for all staff involved is important, as is keeping accurate documentation of the incident. Threatening behaviour can be reported to the police, and dental practices can ultimately exclude the parent, though this would be a last resort. It is highly recommended that practices should have a violence and aggression policy that they can refer to, and that all staff should know who to contact in the practice if they need help.

\section{Final thoughts}

In all of the scenarios discussed, the safety and wellbeing of the child is paramount. Children are not able to protect themselves in the same way that adults can. In all of these situations there is the potential for various outcomes that cannot always be predicted at the start. Concern about the outcome is one of the barriers previously identified as a reason for not referring a child, and we must try to address this concern. It is hoped that by discussing scenarios such as these, dental teams can consider how they will handle all the potential outcomes - from positive outcomes, such as being the first professionals to offer help to struggling families/families in crisis, to families deregistering from a practice and seeking care elsewhere. The whole of the dental team is important as they form part of the wider health and social care teams that look after and support children and families. The importance of being aware of the signs and symptoms of abuse or neglect, recording observations and referring concerns cannot be over-emphasised.

There are currently over 50,000 children identified as needing protection from abuse in the UK and the NSPCC estimate that for every child identified as needing protection from abuse, another eight are suffering abuse. ${ }^{27}$ As dental professionals we must do all we can to protect our young people. 


\section{References}

1. Harris CM, Welbury R, Cairns AM. The Scottish dental practitioner's role in managing child abuse and neglect. Br Dent J . 2013;214(9):E24 DOI:10.1038/sj.bdj.2013.435

2. Cairns AM, Mok JYQ, Welbury RR. The dental practitioner and child protection in Scotland. Br Dent J . 2005;199:517-520.

3. Chadwick BL, Davies J, Bhatia SK, Rooney C, McCusker N. Child protection: training and experiences of dental therapists. Br Dent J . 2009;207:E6.

4. Harris J C, Elcock C, Sidebotham PD, Welbury RR. Safeguarding children in dentistry: I. Child protection training, experience and practice of dental professionals with an interest in paediatric dentistry. Br Dent J . 2009;206:409-414.

5. Saxe MD, MCCourt JW. Child abuse: a survey of ASDC members and a diagnostic-data-assessment for dentists. ASDC J Dent Child. 1991;58:361-366.

6. Von Burg MM, Hibbard RA. Child abuse education: do not overlook dental professionals. ASDC J Dent Child. 1995;62:57-63.

7. J ohn V, Messer LB, Arora R, et al. Child abuse and dentistry: a study of knowledge and attitudes among dentists in Victoria, Australia. Aust Dent J . 1999;44:259-267.

8. Kilpatrick NM, Scott J, Robinson S. Child protection: a survey of experience and knowledge within the dental profession of New South Wales, Australia. Int J Paediatr Dent. 1999;9:153-159.

9. Owais AIN, Qudeimat MA, Qodceih S. Dentists' involvement in identification and reporting of child physical abuse: J ordan as a case study. Int J Paediatr Dent. 2009; 19:291-296.

10. Uldum B, Christensen HN, W elbury R, Poulsen S. Danish dentists' and dental hygienists' knowledge of and experience with suspicion of child abuse or neglect. Int J Paediatr Dent. 2010;20:361-365.

11. Laud A, Gizani S, Maragkou S, W elbury R, Papagiannoulis L. Child protection training, experience, and personal views of dentists in the prefecture of Attica, Greece. Int J Paediatr Dent. 2012; doi:10.1111/j.13651263X.2012.01225.X

12. Criminal J ustice (Scotland) Act 2003. The National Archives UK Legislation site. Available at: www.legislation.gov.uk/asp/2003/7/section/51 Accessed J un 2015.

13. The Children Act 2004. The National Archives UK Legislation site. Available at: www.legislation.gov.uk/ukpga/2004/31/section/58 Accessed J un 2015.

14. The United Nations Convention on the Rights of the Child 1989. United Nations International Children's Emergency Fund (Unicef) site. Available at www.unicef.org.uk/Documents/Publication-pdfs/UNCRC PRESS200910web.pdf Accessed J un 2015. 
15. Harris J, Sidebotham P, Welbury R, et al. Child protection and the dental team. An introduction to safeguarding children in dental practice. Sheffield: Committee of Postgraduate Dental Deans and Directors, 2006. Available at: www.cpdt.org.uk Accessed J un 2015.

16. da Fonseca MA, Feigal RJ, ten Bensel RW. Dental aspects of 1248 cases of child maltreatment on file at a major county hospital. Pediatr Dent. 1992;14:152-157.

17. J essee SA. Child abuse and neglect: implications for the dental profession. Tex Dent J. 1999;116:40-46.

18. Cairns AM, Mok JYQ, Welbury RR. Injuries to the head, face, mouth and neck in physically abused children in a community setting. Int J Paediatr Dent. 2005;15:310318.

19. Greene PE, Chisick MC, Aaron GR. A comparison of oral health status and need for dental care between abused/neglected children and non-abused/non-neglected children. Pediatric Dentistry. 1994;16:41-45.

20. Olivan G. Untreated dental caries is common among 6 to 12-year-old physically abused/neglected children in Spain. Eur J Public Health 2003;13:91-92.

21. Valencia-R ojas N, Lawrence HP, Goodman D. Prevalence of early childhood caries in a population of children with history of maltreatment. J Public Health Dent. 2008;68(2):94-101.

22. Montecchi PP, Di Trani M, Sarzi Amadè D, Bufacchi C, Montecchi F, Polimeni, A. The dentist's role in recognizing childhood abuses: study on the dental health of children victims of abuse and witnesses to violence. Eur J Paediatr Dent. 2009;10(4):185-187.

23. Keene EJ, Skelton R, Day PF, Munyombwe T, Balmer RC. The dental health of children subject to a child protection plan. Int J Paediatr Dent. Epub ahead of print. DOI: $10.1111 /$ ipd.12149

24. Harris CM. Oral disease in vulnerable children and the dentist's role in child protection [MSc Thesis] Glasgow: University of Glasgow; 2013. Available at: http://theses.gla.ac.uk/4150/1/2013harrismsc.pdf.pdf Accessed J un 2015.

25. National Collaborating Centre for Women's and Children's Health, 2009. When to suspect child maltreatment: full guidance. Clinical Guideline 89. National Institute for Health and Clinical Excellence. Royal College of Obstetricians and Gynaecologists: London.

26. General Dental Council. Guidance on child protection and vulnerable adults. 2013. Available at: www.gdcuk.org/Dentalprofessionals/Standards/Documents/Guidance $\% 20$ on $\% 20$ Child\%20P ro 
tection $\% 20$ and $\% 20$ Vulnerable $\% 20$ Adults $\% 20$ November $\% 202013 . p d f$. Accessed J uly 2015.

27. British Dental Association. Bullying, harassment, and violence at work. J une 2014. B ritish Dental Association site. Available at: www.bda.org/dentists/advice/ba/Documents/bda bullying harassment_and violence_at_work__ jun_14.pdf. Accessed J un 2015.

28. NSPCC. Statistics on child abuse. Available at: www.nspcc.org.uk/preventingabuse/research-and-resources/statistics. Accessed J uly 2015. 